\title{
Relasi Ibu-Anak dan Kematangan Emosi Remaja Yatim Duafa
}

\author{
Rizky Hasanah, Efi Fitriana, Marisa Fransiska Moeliono \\ Fakultas Psikologi, Universitas Padjadjaran, Sumedang, Indonesia \\ e-mail: efi.fitriana@unpad.ac.id
}

\begin{abstract}
This study aims to examine association between the mother-child relationship with the emotional maturity of orphan adolescents, using correlational method. Mother-child relationship was measured by the family relation test which consist of 67 items and emotional maturity was measured by the Singh' emotional maturity scale which contains 47 items. The target population of the study was poor orphans aged between 15 and 18 years who live in Cileunyi Bandung. The number of sample was 30 people who were selected by cluster random sampling. Multiple regression is used to test the research hypothesis. The results showed that the mother-child relationship is significantly correlated with emotional maturity at moderate levels. Specifically the mother-child relationship is significantly related to the dimensions of emotional instability and lack of independence but not related to the other three dimensions of emotional maturity (emotional regression, social maladjustment, personality disintegration).
\end{abstract}

Keywords: mother-child relation, emotional maturity, adolescent orphans

\begin{abstract}
Abstrak
Penelitian ini bertujuan mengkaji hubungan antara relasi ibu-anak dengan kematangan emosi remaja yatim duafa, dengan menggunakan metode korelasional. Pengukuran relasi ibu-anak menggunakan kuesioner tes relasi keluarga yang berisi 67 item dan emotional maturity scale dari Singh yang berisi 49 item untuk mengukur kematangan emosi. Target populasi penelitian adalah remaja yatim duafa berusia antara 15 sampai 18 tahun yang berdomisili di Cileunyi Bandung. Sampel dipilih menggunakan metode cluster sampling. Jumlah sampel dari keempat kelurahan tersebut sebanyak 30 orang. Pengujian hipotesis menggunakan analisis regresi berganda. Hasil menunjukkan relasi ibu-anak berhubungan signifikan dengan kematangan emosi dengan kadar hubungan yang moderat. Secara khusus relasi ibu-anak berhubungan signifikan dengan dimensi emotional instability dan lack of independence namun tidak berhubungan dengan tiga dimensi kematangan emosi lainnya (emotional regression, social maladjustment, personality disintegration).
\end{abstract}

Kata Kunci: relasi ibu-anak, kematangan emosi, remaja yatim duafa

\section{Pendahuluan}

Kematangan emosi dapat dicapai melalui perkembangan emosi yang dipengaruhi oleh dua faktor, yaitu peran pematangan (internal) dan hasil belajar (eksternal). Salah satu faktor eksternal yang memengaruhi adalah keluarga (Marliani, dkk., 2020). Orang tua memegang peran penting dalam membimbing remaja menuju kedewasaan. Pada penelitian Mondal dan Sutradhar (2015) terhadap remaja usia 1315 tahun menunjukkan hasil peran orang tua mampu mendukung kemandirian serta kematangan emosi anak. Remaja yang diasuh dalam sebuah keluarga yang kedua orang tuanya lengkap memungkinkan mereka lebih mampu mencapai kematangan emosi dibandingkan dengan remaja dari keluarga tidak lengkap (Nashukah \& Darmawanti, 2013). Fenomena yang terjadi pada anak yatim telah menjadi perhatian beberapa peneliti sebab ketika seorang remaja hidup tanpa keberadaan ayah dapat memberikan perubahan pada diri remaja. Yuliawati dkk. (2007) menemukan bahwa terdapat permasalahan terhadap perilaku dan emosi remaja usia 13-18 tahun yang tidak lagi memiliki ayah. 
Masalah perilaku yang muncul yaitu remaja lebih sulit untuk diatur oleh ibu dan mereka jarang berada di rumah. Yuniana (2012) meneliti kesejahteraan subjektif remaja yatim usia 18-22 tahun menemukan hasil bahwa remaja merasa kurang berarti dan berharga, mudah menangis jika teringat orang tua dan ketika mengalami banyak masalah, cenderung menghindari orang lain dan lingkungan jika tidak nyaman. Ditemukan pula oleh Chairani (2014) bahwa kematian salah satu atau kedua orang tua menimbulkan rasa kehilangan pada diri remaja. Kehilangan yang dirasakan adalah kehilangan kasih sayang dan perhatian, kehilangan role model, kehilangan rasa aman, kehilangan keutuhan keluarga, dan kehilangan arah. Dampak kesepian yang dirasakan remaja yatim piatu diantaranya merasakan rendah diri sehingga sering menghindar dan menjauh dari situasi ramai, menyalahkan diri sendiri karena dilahirkan tanpa ada orang tua yang mampu membimbing dan memberikan perhatian, takut bertemu orang lain dan menghindari situasi baru, serta merasakan keterasingan dan kesendirian (Sudarman, 2010). Faktor kedekatan anak dengan orang tua lebih menentukan kondisi psikologis anak daripada struktur keluarga. Keluarga yang memberikan perhatian cukup, penuh rasa kasih sayang, penghormatan terhadap diri personal, keterbukaan dan sikap penerimaan, serta suasana humoris dapat memengaruhi cara pengelolaan emosional individu. Untuk mendukung pencapaian kematangan emosi remaja maka selain keberadaan orang tua, remaja juga membutuhkan kedekatan secara emosional dengan ayah atau ibu (Hamalik, 2004 dalam Yuliawati dkk., 2007).

Kedekatan fisik seorang anak dengan orang tuanya merupakan salah satu dimensi dalam relasi ibu-anak seperti diungkap dalam binding dan loyalty theory yang menjadi dasar menyusun pengukuran enam dimensi relasi ibu-anak (Oud \& Welzen, 1989). Keenam dimensi tersebut meliputi pembatasan, afeksi, kepekaan, keadilan, pengakuan dan kepercayaan. Seperti halnya temuan beberapa peneliti, relasi ibu-anak berhubungan dengan kematangan emosi seorang remaja ditemukan pula oleh Armsden dan Greenber (1987), secara khusus dengan kestabilan emosi (Barmola, 2014) dan kemandirian (Karabanova \& Poskrebysheva, 2013). Selain dimensi kestabilan emosi, kemandirian, terdapat pula tiga dimensi kematangan emosi lainnya pada penelitian ini regresi emosi, kemampuan sosial, dan integrasi kepribadian (Singh \& Bhargava, 1990).

Kondisi perekonomian keluarga dapat pula memberikan pengaruh dalam perkembangan seorang remaja seperti yang dinyatakan oleh Liputo (2014) yakni ketika hidup dalam keluarga yang tergolong lemah secara ekonomi maka semakin meningkat pula persoalan-persoalan kehidupan yang akan dialami seseorang. Singh dkk. (2014) menemukan adanya perbedaan kematangan emosi remaja berdasarkan kelas ekonomi keluarga. Remaja dari keluarga dengan tingkat ekonomi tinggi dan menengah ke atas secara signifikan lebih matang secara emosional dibandingkan remaja dari keluarga dengan tingkat ekonomi rendah.

Penelitian tentang anak yatim masih menjadi perhatian para peneliti mengingat jumlah anak yatim di Indonesia mencapai 3.2 juta jiwa (Ucu, 2013). Terdapat pula banyak yayasan pengelola anak yatim di Indonesia salah satunya Lembaga Amil Zakat Nasional Yatim Mandiri wilayah Bandung. Yatim Mandiri memiliki kurang lebih 120 anak asuh di sekitar kota Bandung. Di kecamatan Cileunyi kabupaten Bandung terdapat sebuah yayasan Relawan Pecinta Yatim Duafa (Rapiya). Hingga saat ini, Rapiya telah menyantuni sekitar 146 anak yatim dari berbagai desa di Kecamatan Cileunyi.

Perhatian dari beberapa peneliti terhadap anak yatim dan kontribusi yayasan pengelola anak yatim menginspirasi peneliti untuk turut pula berkontribusi terhadap anak yatim. Inspirasi tersebut 
didasarkan pula oleh pertimbangan remaja yatim merupakan generasi penerus bangsa yang perlu dipersiapkan dalam menghadapi masa depannya. Oleh karena itu, pertanyaan penelitian ini adalah apakah terdapat hubungan antara relasi ibu-anak dengan kematangan emosi remaja yatim duafa.

\section{Metode Penelitian}

\section{Rancangan penelitian}

Penelitian ini pendekatan kuantitatif dan metode penelitian korelasional. Penelitian noneksperimental adalah penelitian dimana variabel tidak dimanipulasi oleh peneliti. Pendekatan kuantitatif sebagai salah satu cara untuk mengumpulkan beberapa tipe data numerik untuk menjawab masalah penelitian yang diberikan. Sedangkan metode korelasional merupakan suatu metode penelitian yang mendeskripsikan derajat hubungan yang ada di antara dua variabel yang diukur (Christensen, 2011).

\section{Subjek Penelitian}

Target populasi penelitian adalah remaja yatim miskin berusia antara 15 sampai 18 tahun yang berdomisili di kecamatan Cileunyi kabupaten Bandung. Sampel dipilih menggunakan metode cluster random sampling. Dari enam kelurahan di kecamatan Cileunyi terpilih secara random empat kelurahan yaitu Cileunyi Kulon, Cibiru Hilir, Cibiru Wetan, Cileunyi Wetan dan Cimekar. Ukuran sampel berjumlah 30 orang yang mengacu pada perumusan ukuran sampel minimal untuk studi korelasional (Hulley dkk., 2007) berikut ini:

$$
\begin{aligned}
& n=\left[\left(Z_{\mathrm{x}}+Z_{\beta} \div C\right)\right]^{2}+3, \text { dengan } \\
& C=0.5 \times \ln [(1+r) \div(1-r)] \text { dan } \\
& \propto \text { dan } \beta=0.05 \text { dan r yang diharapkan }=0.6
\end{aligned}
$$

Rata-rata subjek berusia $16.13(\mathrm{SB}=$ .94). Mayoritas subjek penelitian berjenis kelamin laki-laki sebanyak 16 orang (53.3\%.) Sebanyak 12 orang (40\%) merupakan anak bungsu dalam keluarganya. Sebanyak 17 orang $(56.7 \%)$ memiliki ibu sebagai ibu rumah tangga, serta sebanyak 20 orang $(66.7 \%)$ tergolong berada pada keluarga dengan kategori status ekonomi sosial (SES) rendah. Karakteristik populasi pada penelitian ini yaitu remaja yatim duafa usia 15 - 18 tahun yang tinggal bersama ibunya di kecamatan Cileunyi. Duafa adalah orang yang lemah dari segi ekonomi menurut kamus besar bahasa Indonesia. Kondisi duafa subjek dibuktikan dengan menunjukkan kepemilikan surat keterangan tidak mampu dari kecamatan.

\section{Pengukuran}

Pada penelitian ini data dikumpulkan menggunakan alat ukur berupa kuesioner yang berbentuk skala. Data persepsi remaja tentang relasinya dengan ibu dijaring menggunakan kuesioner yang bernama tes relasi keluarga Bandung (TRK-B). Tes ini merupakan hasil adaptasi dari tes relasi keluarga versi Belanda yang bernama the Nijmeegse Gezinsrelatie Test (NGT), (Fitriana, 2011). Pada TRK-B terdapat enam dimensi relasi terdiri dari pembatasan, afeksi, kepekaan, keadilan, pengakuan dan kepercayaan yang dituangkan ke dalam 67 item. Terdapat item positif dan negatif. Setiap item memiliki lima skala pilihan jawaban hampir mirip dengan Likert. Skala menggambarkan kesesuaian pernyataan dengan keadaan responden. Skala item dan skor untuk item positif adalah "ya-ya" $=5$, "ya"=4, "0"=3, "tidak"=2, "tidak-tidak" $=1$. Item negatif memiliki skor dengan arah yang berbeda dengan item positif. Contoh item TRK-B: "Bila saya berada dalam kesusahan saya tahu bahwa Ibu akan turut merasakannya". Analisis validitas TRK-B pada proses adaptasi menggunakan confirmatory factor analysis (CFA). Hasil analisis validitas konstruk menunjukkan konstruk relasi keluarga fit dengan kondisi 
Indonesia ditunjukkan oleh dua fit indeks, root mean square error approximation $($ RMSEA $=.06)$ dan comparative fit index $(C F I=.97)$. Analisis reliabilitas Cronbach Alpha berdasarkan studi adaptasi TRK-B menunjukkan koefisien reliabilitas berkisar antara .66 - .78 (Moeliono dkk., 2018), pada penelitian ini diperoleh koefisien reliabilitas berkisar antara .69 - .92.

Untuk mengukur variabel kematangan emosi digunakan emotional maturity scale (EMS) (Singh \& Bhargava, 1990). Alat ukur ini berupa kuesioner self administered yang terdiri atas 47 item. Sistem skor setiap item 5 pilihan jawaban berskala Likert yaitu: 5 (sangat sesuai), 4 (sesuai), 3 (ragu-ragu), 2 (tidak sesuai), 1 (sangat tidak sesuai). Semua kalimat pada alat ukur ini menggunakan kata-kata yang merujuk kepada ketidakmatangan emosi sehingga semakin tinggi skor yang didapatkan menggambarkan ketidakmatangan emosi seseorang. Butir pernyataan diturunkan dari dimensi-dimensi kematangan emosi yaitu: emotional instability, emotional regression, social maladjustment, personality disintegration, dan lack of independence. Alat ukur EMS berbahasa Inggris, sehingga pada penelitian ini dilakukan proses translasi mengacu pada "The International Test Commission Guidelines for Translating and Adapting Tests (Second Edition)," (2018). Proses tersebut meliputi: 1) pre-condition merupakan proses persiapan sebelum translasi diantaranya meminta izin terlebih dahulu kepada pemilik alat ukur, 2) translasi menggunakan metode forward translation dan backward translation yaitu proses yang melibatkan ahli bahasa untuk melakukan translasi dari bahasa asli (bahasa Inggris) ke bahasa yang ditujukan (bahasa Indonesia), selanjutnya back translation yaitu mentranslasikan kembali kuesioner ke bahasa aslinya (bahasa Inggris), 3) expert review, dalam tahapan ini hasil terjemahan dinilai kembali oleh ahli baik dari segi konten maupun bahasa, dan 4) uji coba alat ukur yang melibatkan beberapa responden. Pada tahap ini dilakukan analisis psikometri untuk mengevaluasi aspek reliabilitas dari alat ukur. Contoh item EMS: "Saya merasa iri terhadap orang lain". Koefisien reliabilitas menggunakan metode test-retest berkisar antara .42 - .86 (Singh dan Bhargava, 1990). Pada tahapan uji coba diperoleh koefisien reliabilitas Alpha Cronbach berkisar antara $.51-.87$.

\section{Analisis Statistik}

Analisis statistik deskriptif digunakan untuk memberikan gambaran mengenai relasi ibu-anak dan kematangan emosi remaja duafa. Data demografi meliputi jenis kelamin, usia, urutan kelahiran dan jumlah saudara, pekerjaan ibu, serta sosial ekonomi dan status keluarga responden. Analisis deskriptif data kategorikal menggunakan frekuensi absolut dan persentase, sedangkan data numerikal menggunakan rata-rata dan simpangan baku.

Analisis statistik inferensial untuk pengujian hipotesis dilakukan menggunakan korelasi multiple. Alasan menggunakan metode tersebut mengingat variabel relasi ibu-anak memiliki enam dimensi yang secara simultan dikorelasikan dengan total skor kematangan emosi. Korelasi bivariat dari Pearson dihitung pula untuk mengetahui hubungan antar dua variabel.

\section{Hasil Penelitian dan Pembahasan}

\section{Hasil penelitian}

Berdasarkan rata-rata skor skala (tabel 1) dapat digambarkan relasi ibu-anak seorang remaja menunjukkan skor terbesar pada dimensi afeksi. Hal ini menunjukkan relasi kedekatan fisik dengan ibunya lebih banyak dirasakan oleh remaja yatim duafa. Secara umum remaja yatim duafa memiliki kematangan emosi yang tinggi, hal ini ditunjukkan oleh skor rata-rata skala kematangan emosi yang cenderung berada pada skala 2. Subjek penelitian menunjukkan tidak memiliki gejala disintegrasi kepribadian, dapat berpikir 
rasional, tidak pesimis dan tidak melakukan tindakan yang melanggar moral. Hal tersebut didukung oleh skor skala personality disintegration mendekati pilihan 2.

Keragaman respon melalui skor SB pada tabel 1 mengenai relasi ibu-anak pada remaja yatim duafa paling tinggi ditunjukkan oleh dimensi pembatasan. Gambaran ini menunjukkan ada remaja yang memiliki persepsi bahwa ibu sangat banyak memberikan pembatasan atau aturan-aturan namun ada pula yang tidak demikian. Sedangkan pada kematangan emosi, respon subjek penelitian menunjukkan keragaman paling tinggi pada dimensi kestabilan emosi. Hal tersebut dapat diartikan ada remaja yang merasa emosinya sangat stabil ada pula yang merasa tidak stabil.

Pengujian hipotesis mengenai hubungan relasi ibu-anak dengan kematangan emosi remaja yatim, baik keenam dimensi relasi dengan skor total kematangan emosi maupun dengan setiap dimensi kematangan emosi dapat dilihat pada tabel 2 .

Tabel 1

Profil Relasi Ibu-Anak serta Kematangan Emosi

\begin{tabular}{llll}
\hline \multirow{2}{*}{ Variabel } & \multicolumn{1}{c}{ Dimensi } & Rata- \\
Rata & SB \\
\hline Relasi & Pembatasan & 2.40 & 5.15 \\
ibu-anak & Afeksi & 3.99 & 3.74 \\
& Kepekaan & 3.77 & 3.82 \\
& Keadilan & 3.59 & 4.83 \\
& Pengakuan & 3.70 & 4.68 \\
Kematangan & Kepercayaan & 3.53 & 4.59 \\
emosi & Kematangan emosi & 2.30 & 3.30 \\
& Emotional Instability & 2.48 & 6.60 \\
& Emotional Regression & 2.23 & 4.34 \\
& Social Maladjustment & 2.16 & 4.00 \\
& Personality & 1.98 & 3.64 \\
& Disintegration & & \\
& Lack of Independence & 2.61 & 3.83 \\
\hline
\end{tabular}

Tabel 2

Analisis Regresi Multipel Dimensi Relasi Ibu-Anak dengan Kematangan Emosi

\begin{tabular}{|c|c|c|c|c|}
\hline & \multicolumn{3}{|c|}{ Adjusted } & \multirow[b]{2}{*}{ Sig. } \\
\hline & $R$ & $R^{2}$ & $F(6,23)$ & \\
\hline $\begin{array}{l}\text { Kematangan } \\
\text { emosi }\end{array}$ & .65 & .28 & 2.85 & $.03 *$ \\
\hline $\begin{array}{l}\text { Emotional } \\
\text { instability }\end{array}$ & .66 & .29 & 2.96 & $.03 *$ \\
\hline $\begin{array}{l}\text { Emotional } \\
\text { regression }\end{array}$ & .62 & .22 & 2.35 & .06 \\
\hline $\begin{array}{l}\text { Social } \\
\text { maladjustment }\end{array}$ & .62 & .22 & 2.39 & .06 \\
\hline $\begin{array}{l}\text { Personality } \\
\text { disintegration }\end{array}$ & .57 & .14 & 1.79 & .15 \\
\hline $\begin{array}{l}\text { Lack of } \\
\text { independence }\end{array}$ & .65 & .28 & 2.87 & $.01 *$ \\
\hline
\end{tabular}

Hasil menunjukkan keenam dimensi relasi ibu-anak secara simultan memiliki hubungan signifikan dengan total kematangan emosi, dimensi emotional instability dan lack of independence yang masing-masing memiliki nilai signifikansi $.03, .03$, dan .01 , yang nilainya lebih kecil dari $\propto=5 \%$. Koefisien korelasi multiple $\mathrm{R}$ antara enam dimensi relasi ibu-anak dengan kematangan emosi, dimensi emotional instability dan lack of independence menunjukkan koefisien yang tergolong sedang yaitu .65, .66, dan .65. Dapat dimaknakan bahwa jika kematangan emosi dianggap sebagai satu kesatuan maka keenam dimensi relasi ibu dan anak dapat menjelaskan perubahan skor kematangan emosi sebesar $27.7 \%$, perubahan dimensi emotional instability sebesar $28.9 \%$, dan perubahan sebesar $27.9 \%$ terhadap dimensi lack of independence.

Jika ditinjau secara parsial, hubungan skor setiap dimensi relasi ibu-anak dengan skor total kematangan emosi (tabel 3), tampak setiap dimensi relasi ibu-anak memiliki hubungan signifikan dengan kematangan emosi, kecuali dimensi kepekaan. 
Tabel 3

Korelasi Dimensi Relasi Ibu-Anak dengan Kematangan Emosi

\begin{tabular}{|c|c|}
\hline Dimensi & $\begin{array}{c}\text { Kematangan } \\
\text { Emosi }\end{array}$ \\
\hline Pembatasan & $.47^{* *}$ \\
\hline Afeksi & $-.39^{*}$ \\
\hline Kepekaan & -.23 \\
\hline Keadilan & $-.52^{* *}$ \\
\hline Pengakuan & $-.44^{* *}$ \\
\hline Kepercayaan & $-.59^{* *}$ \\
\hline
\end{tabular}

Catatan: **Signifikan pada $\propto=1 \%$, *Signifikan pada $\propto$ c $=5 \%$

Mengacu pada pemaknaan skor alat ukur kematangan emosi, maka hasil pada tabel 3 dapat dimaknakan bahwa terdapat empat dimensi relasi ibu-anak (afeksi, keadilan, pengakuan dan kepercayaan) memiliki hubungan yang searah dengan kematangan emosi. Hal tersebut dapat dimaknakan semakin dekat seorang ibu secara fisik dengan anak remajanya maka akan semakin matang emosi remaja tersebut. Begitu pula jika semakin baik seorang ibu menerapkan keadilan, memberikan pengakuan dan kepercayaan yang baik pada anak remajanya maka akan semakin matang kondisi emosi anak remaja tersebut. Tidak demikian halnya dengan dimensi pembatasan, memiliki hubungan berlawanan arah dengan kematangan emosi, sehingga dapat dimaknakan bahwa semakin banyak aturan yang diterapkan ibu kepada anaknya maka semakin tidak matang emosi remaja dan sebaliknya. Dimensi kepekaan menunjukkan tidak memiliki hubungan yang signifikan dengan kematangan emosi.
Hasil pada tabel 4 menunjukkan analisis hubungan antara setiap dimensi relasi ibu-anak dengan setiap dimensi kematangan emosi. Jika ditinjau dari setiap dimensi kematangan emosi, diperoleh hasil bahwa stabilitas emosi seorang remaja yatim duafa berhubungan signifikan dengan seberapa besar aturan atau pembatasan yang diberikan oleh ibunya. Semakin banyak pembatasan yang diterima oleh seorang remaja maka akan semakin tidak stabil kondisi emosi remaja tersebut. Namun remaja akan memiliki kestabilan emosi yang tinggi jika dia diberikan kepercayan yang tinggi pula oleh ibunya. Emotional regression yang rendah akan sejalan dengan seringnya seorang remaja mendapatkan afeksi, keadilan, pengakuan dan kepercayaan dari ibunya. Social maladjustment tidak memiliki hubungan signifikan dengan setiap dimensi relasi ibuanak. Kematangan integrasi kepribadian berhubungan signifikan dengan empat dimensi relasi ibu-anak yaitu pembatasan, afeksi, keadilan dan kepercayaan. Tingginya afeksi, keadilan dan kepercayaan yang diberikan oleh seorang ibu pada anak remajanya akan sejalan dengan semakin matangnya integrasi kepribadian remaja tersebut. Tidak demikian halnya dengan banyaknya aturan yang diberikan seorang ibu maka akan sejalan dengan rendahnya kematangan integrasi kepribadian anak remajanya. Kemandirian seorang remaja akan meningkat sejalan dengan meningkatnya dimensi afeksi, kepekaan, keadilan, pengakuan dan kepercayaan yang

Tabel 4

Korelasi Dimensi Relasi Ibu-Anak dengan Dimensi Kematangan Emosi

\begin{tabular}{lccccc}
\hline & $\begin{array}{c}\text { Emotional } \\
\text { Instability }\end{array}$ & $\begin{array}{c}\text { Emotional } \\
\text { Regression }\end{array}$ & $\begin{array}{c}\text { Social } \\
\text { Maladjustment }\end{array}$ & $\begin{array}{c}\text { Personality } \\
\text { Disintegration }\end{array}$ & $\begin{array}{c}\text { Lack of } \\
\text { Independence }\end{array}$ \\
\hline Pembatasan & $.43^{*}$ & $.41^{*}$ & .30 & $.39^{*}$ & .35 \\
Afeksi & -.23 & $-.49^{* *}$ & .11 & $-.41^{*}$ & $-.56^{* *}$ \\
Kepekaan & .00 & -.34 & .06 & -.21 & $-.48^{* *}$ \\
Keadilan & -.36 & $-.53^{* *}$ & -.30 & $-.48^{* *}$ & $-.39^{*}$ \\
Pengakuan & -.27 & $-.53^{* *}$ & -.20 & -.34 & $-.41^{*}$ \\
Kepercayaan & $-.53^{* *}$ & $-.56^{* *}$ & -.25 & $-.47^{* *}$ & $-.53^{* *}$ \\
\hline
\end{tabular}

Catatan :** Signifikan pada level .01, * Signifikan pada level .05 
diberikan oleh ibu remaja tersebut. Koefisien korelasi yang signifikan berkisar antara .39 sampai .56 yang tergolong moderat (Dancey \& Reidy, 2014).

\section{Pembahasan}

Relasi ibu dengan remaja yatim dan duafa, yang terdiri dari pembatasan, afeksi, kepekaan, keadilan, pengakuan, dan kepercayaan, secara simultan memiliki hubungan yang signifikan dengan kematangan emosi remaja ini. Hal ini sejalan dengan Collins dan Laursen (2004) yang membuktikan bahwa relasi yang terbentuk antara orang tua dan anak berpengaruh terhadap keterampilan sosial dan emosional anak.

Penghayatan remaja yatim tentang relasi ibu dengan remaja yatim duafa yang terdiri dari pembatasan, afeksi, kepekaan, keadilan, pengakuan, dan kepercayaan, secara simultan memiliki hubungan yang signifikan dengan emotional instability. Temuan pada penelitian ini sejalan dengan yang ditemukan oleh Barmola (2014) mengenai peran relasi orang tua dan anak terhadap pembentukan emotional stability anak remaja.

Data menunjukkan bahwa kebanyakan remaja yatim duafa menghayati bahwa ibu mereka tidak melakukan pembatasan yang berlebihan sehingga menghambat dan membuat mereka tidak nyaman. Bentuk pembatasan yang banyak dihayati remaja antara lain adalah melarang mereka terlalu banyak pergi bermain. Namun demikian ibu mereka bukanlah sosok yang menyalahkan, mereka melihat ibu sebagai ibu yang berusaha menerapkan norma yang berlaku tanpa memberi banyak tuntutan yang membatasi ruang gerak mereka. Hasil penelitian mendukung konsep alat ukur relasi orang tua anak yang digunakan yaitu bahwa pembatasan merefleksikan persepsi anak mengenai orang tua sebagai sosok normatif dan sejauhmana anak mengalami pembatasan dari orang tua (Oud \& Welzen, 1989). Hasil penelitian Fellasari dan Lestari (2016) menunjukkan bahwa ketidakmatangan emosi terjadi ketika orang tua dirasakan terlalu mengendalikan remaja dengan menerapkan terlalu banyak aturan dengan keras. Hal serupa diungkap pula Santiago dkk. (2019) yaitu faktor kritik dan penolakan ibu terkait secara signifikan dengan ketidakstabilan emosi yang dirasakan remaja.

Hal ini tidak terjadi pada remaja yatim duafa sehingga mereka tidak merasa tertekan ataupun merasa perlu menunjukkan sikap atau perilaku menentang dan memberontak pada ibu, hal ini mendukung stabilitas emosi mereka. Hal ini baik bagi remaja yatim duafa sehingga mereka diharapkan tidak akan mengalami gejala depresi dan kecemasan karena pembatasan berlebihan seperti yang ditunjukkan dalam penelitian Skoczen dkk. (2015). Temuan mengenai bentuk-bentuk stabilitas emosi pada remaja yatim duafa ini antara lain adalah mereka mampu bertahan mengerjakan tugas-tugas mereka hingga tuntas. Lebih dari separuh remaja yatim duafa ini mengatakan bahwa mereka masih mampu mengendalikan diri saat mereka merasakan kemarahan dalam diri mereka, sehingga tidak menunjukkan perilaku agresi. Remaja yatim duafa ini tidak memiliki rasa iri hati pada orang lain. Relasi ibu dengan remaja yatim duafa yang tidak menerapkan pembatasan secara berlebihan membuat remaja merasa lebih tenang dalam menjalani kehidupan mereka. Hal serupa ditemukan pada penelitian Tidarsari dan Muhariati (2017) yang menunjukkan bahwa untuk mencapai kestabilan emosi anak tetap memerlukan bimbingan dari orang tua yang bisa merupakan pemberian aturan. Namun dengan adanya sikap orang tua yang terbuka dalam membuat aturan-aturan yang disepakati bersama dengan anak terutama yang sudah remaja akan menghasilkan stabilitas emosi anak remajanya. Remaja yang merasakan bimbingan yang tepat dari orang tua akan mampu belajar mengelola emosi mereka saat berhubungan dengan 
diri sendiri maupun saat mereka berhubungan dengan orang lain.

Dalam penelitian ini terlihat bahwa penghayatan remaja yatim duafa tentang relasi ibu dengan mereka yang terdiri dari pembatasan, afeksi, kepekaan, keadilan, pengakuan, dan kepercayaan, secara simultan memiliki hubungan yang signifikan dengan lack of independence. Data penelitan pada remaja yatim duafa ini menunjukkan bahwa saat ibu mereka berelasi dengan mereka, ibu menunjukkan afeksi, kepekaan, keadilan, pengakuan, dan kepercayaan dan hal inilah yang membuat mereka menjadi mandiri dan tidak merasa perlu bergantung pada orang lain. Mondal dan Sutradhar (2015) menyajikan hasil bahwa ada efek yang signifikan dari lingkungan rumah terhadap kematangan emosi remaja. Peran orang tua mampu mendukung kemandirian serta kematangan emosi anak. Keluarga memiliki peran membantu mempersiapkan remaja untuk menjalankan peran dan fungsinya dalam masyarakat. Remaja yang independen yakni mereka yang tidak bergantung kepada orang lain dalam melakukan tugas, mampu mengambil keputusan dan tidak egois (Singh \& Bhargava, 1990). Hasil penelitian menunjukkan bahwa menurut kebanyakan remaja yatim duafa ini orangorang menganggap mereka bertanggung jawab, lebih dari setengah jumlah remaja yatim duafa penelitian ini tidak suka menjadi pengikut, dan mengaku bahwa orang-orang tidak ragu menerima bantuan yang mereka berikan. Sehingga dapat dikatakan bawa remaja yatim duafa ini menghayati bahwa relasi mereka dengan ibu membuat mereka menjadi remaja yang tidak bergantung pada orang lain.

Hampir seluruh responden merasa senang ketika ibu mereka berada di dekatnya, mereka merasa senang ketika mereka memiliki waktu untuk dapat duduk nyaman bersama ibu, merasa senang ketika ibu memeluk dan mencium mereka. Semakin banyak perilaku ibu yang ditandai dengan relasi intim dalam bentuk kedekatan secara fisik maka remaja yatim duafa ini akan semakin menunjukkan kematangan emosional. Temuan ini sejalan dengan hasil penelitian Armsden dan Greenber (1987) yaitu bahwa afeksi yang terbentuk saat ibu dan anaknya berinteraksi yang ditunjukkan dengan kedekatan fisik dan kedekatan emosi dapat mendukung kematangan emosi remaja. Temuan penelitian tersebut menunjukkan pentingnya afeksi dalam relasi ibu-anak karena ketika terjalin hubungan yang aman antara orang tua dan remaja hal tersebut akan dapat mengembangkan harga diri yang lebih baik dan kesejahteraan emosi yang lebih baik pada diri remaja.

Dalam hal keadilan yang merefleksikan keseimbangan dalam give and take antara ibu dengan anak remajanya menunjukkan bahwa penghayatan kebanyakan responden remaja yatim duafa ini menilai bahwa ibu banyak berbuat untuknya dan bahwa ia pun menunjukkan kesediaan untuk berbuat sesuatu sebagai balasannya. Dari penelitian Skoczn dkk. (2015) remaja yang menunjukkan perilaku prososial menghayati perlakuan adil orang tuanya. Sehingga diharapkan remaja yang sudah tidak lagi memiliki ayah dan dalam keadaan kondisi tidak sepenuhnya terpenuhi secara ekonomi, hanya hidup dengan ibu sebagai orang tua, dan menghayati bahwa mereka diperlakukan dan dapat berlaku adil dengan ibu mereka, mereka akan dapat melihat dunia sebagai tempat yang adil dan memiliki kecenderungan lebih untuk menolong orang lain seperti yang ditemukan dalam penelitian. Murray (2003) menguraikan individu yang mendapatkan perlakuan adil akan berkembang menjadi individu yang akan memperlakukan hidup secara adil pula. Mereka memiliki kecenderungan untuk mempertimbangkan kebutuhan orang lain dan memberikan sumber daya pribadinya, baik dalam bentuk materi maupun imateriil seperti waktu dan upaya dari dirinya untuk meningkatkan kualitas hidup orang-orang yang dicintainya. Begitu 
pun sebaliknya, mereka juga akan membiarkan orang lain memberikan sesuatu kepada mereka. Ketidakmatangan diindikasikan dengan bersedia memberi tetapi tidak mau menerima atau bersedia menerima tetapi tidak mau memberi.

Penghayatan remaja yatim duafa ini dalam hal pengakuan berupa penghargaan ibu, pujian atau pertolongan sebagai respon positif terhadap tampilan remaja ketika ia menyatakan pendapat, menunjukkan kemampuan berdasarkan bakat yang ia miliki berpengaruh pada kematangan emosi mereka. Responden merasa bahwa ibu menghargai keberadaan dan perilakunya, mayoritas remaja yatim duafa dalam penelitian ini menyatakan bahwa ibu membutuhkan mereka, mereka menganggap ibu menampilkan perilaku yang memperlihatkan bahwa mereka berarti bagi ibu, remaja juga menyatakan bahwa ibu akan senang ketika mereka memberikan bantuan dalam segala hal yang ibu lakukan.

Dalam penelitian ini terlihat bahwa semakin remaja merasakan dan mampu menaruh kepercayaan saat berelasi dengan ibu mereka, maka mereka semakin menunjukkan ciri-ciri kematangan sosial. Kepercayaan merepresentasikan persepsi anak bahwa orang tuanya sebagai sosok yang bertanggung jawab dan dapat diandalkan (Oud \& Welzen, 1989). Temuan pada pengolahan data dalam hal kepercayaan ini bahwa mayoritas jawaban remaja yatim duafa menunjukkan kesediaan untuk meminjamkan barang miliknya kepada ibu, mereka menyatakan bahwa mereka jarang berbeda pendapat dengan ibu dan lebih sering memiliki kesesuaian pendapat dengan pendapat atau perkataan ibu. Adanya kepercayaan remaja yatim duafa terhadap ibu terlihat dari sebagian besar remaja ini akan mencari ibu mereka untuk menceritakan permasalahan yang membuat mereka pusing.

Dalam penelitian ini ditemukan bahwa kepekaan dalam relasi ibu dan remaja yatim tidak mempunyai kaitan dengan kematangan emosi remaja. Temuan penelitian ini tidak sejalan dengan definisi dimensi kepekaan yang menggambarkan seberapa mampu anak untuk turut mengenali dan dapat mengekspresikan rasa empati serta memiliki keterlibatan baik melalui pikiran ataupun perasaan terhadap rasa sakit, kesepian, atau kesedihan dari anggota keluarga lain. Tidak sejalan pula dengan pernyataan orang yang matang secara emosional akan menunjukkan kepekaan dan memiliki kemampuan untuk mempercayai orang lain dan memiliki keterbukaan terhadap cinta dan kasih sayang (Murray, 2003; Kapri \& Rani, 2014).

Hubungan antara dimensi afeksi, kepekaan, keadilan, pengakuan, dan kepercayaan dengan dimensi lack of independence menunjukkan hasil uji yang signifikan. Dimana skor tinggi pada dimensi afeksi, kepekaan, keadilan, pengakuan, dan kepercayaan berhubungan dengan skor rendah pada lack of independence. Remaja yang independen yakni mereka yang tidak bergantung kepada orang lain dalam melakukan tugas, mampu mengambil keputusan dan tidak egois (Singh \& Bhargava, 1990). Hasil penelitian ini menunjukkan bahwa pada umumnya subjek penelitian menyatakan bahwa orang-orang menganggap mereka bertanggung jawab, tidak suka menjadi pengikut, dan orang-orang tidak ragu menerima bantuan yang mereka berikan. Dari hasil tersebut menunjukkan mayoritas responden berusaha tidak bergantung pada orang lain. Hasil serupa dengan penelitian ini seperti yang ditemukan oleh Karabanova dan Poskrebysheva (2013) terdapat hubungan antara relasi orang tua dan remaja terhadap tingkat kemandirian yang dimiliki remaja. Remaja yang merasa puas akan hubungannya dengan orang tua dan memiliki kedekatan emosional terutama dengan ibu sehingga bersedia berbagi dan bercerita hal-hal penting dengan orang tua yang dianggapnya hangat dan berempati. Remaja dengan kemandirian yang tinggi dicirikan oleh 
kontrol orang tua yang rendah, memberikan kebebasan, peka terhadap kebutuhan dan minat remaja, sering melakukan kegiatan bersama, siap mendengarkan ketika remaja bercerita, menunjukkan cinta, dan orang tua bersedia mengakui ketika mereka salah dan meminta maaf. Suara remaja juga turut dipertimbangkan saat membuat keputusan keluarga. Remaja yang merasa independen menganggap hubungannya dengan orang tua sebagai memuaskan. Remaja yang memiliki kemandirian rendah dicirikan dengan kontrol yang tinggi dari orang tua dan mengakui adanya otoritas dari ibu. Orang tua ingin remaja untuk meniru mereka dan merasa pendapat mereka yang paling benar, terdapat sikap inkonsisten dari orang tua serta tidak adanya kerjasama dalam hubungan orang tua dan remaja. Tingginya kontrol, jarak emosional, tidak ada ruang untuk bekerjasama menjadikan remaja kurang memiliki kemandirian sehingga menghambat perkembangan sosial remaja dan berkaitan dengan sikap dan keyakinan remaja dalam pengambilan keputusan.

\section{Simpulan}

Terdapat hubungan yang signifikan antara keenam relasi ibu-anak dengan total kematangan emosi, dengan dimensi emotional instability dan lack of independence pada remaja yatim duafa usia 15-18 tahun di Kecamatan Bandung, namun tidak berhubungan signifikan dengan dimensi emotional regression, social maladjustment, dan personality disintegration.

\section{Daftar Pusataka}

Armsden, G. C., \& Greenber, M. T. (1987). The inventory of parent and peer attachment: Individual differences and their relationship to psychological well-being in adolescence. Journal of Youth and Adolescence, 16, 427-454. https://doi.org/10.1007/BF02202939
Barmola, K. C. (2014). Emotional stability and parent-child relationship. Journal of Multidisciplinary Educational Research, 3(4), 169-176.

Christensen, L. B. (2011). Experimental methodology 10th edition. Allyn and Bacon.

Collins, W. A., \& Laursen, B. (2004). Parent-adolescent relationships and influences. Dalam R. Lerner \& L. Steinberg, Handbook of adolescent psychology (2nd ed.). John Wiley \& Sons, Inc.

Dancey, C., \& Reidy, J. (2011). Statistics without maths for psychology (5th ed.). Pearson Education Limited.

Fellasari, F., dan Lestari, Y. I. (2016). Hubungan antara pola asuh orang tua dengan kematangan emosi remaja. Jurnal Psikologi, 12(2), 84-90.

Fitriana, E. (2011). Confirmatory factor analysis of the Bandung family relation test: a stimulation study comparing $\mathrm{ml}$, $d w l s$, and wls estimation (Disertasi tidak diterbitkan). Universitas Padjadjaran, Fakultas Psikologi.

Hurlock, E. B. (1980). Psikologi perkembangan suatu pendekatan sepanjang rentang kehidupan edisi kelima. Penerbit Erlangga.

ITC Guidelines for Translating and Adapting Tests (Second Edition). (2018). International Journal of Testing, 18(2), 101-134. https://doi.org/10.1080/15305058.2017 .1398166

Hulley, S. B., Cummings, S. R., Browner, W. S., Grady, D. G., \& Newman, T. B. (2007). Designing clinical research third edition. Lippincott Williams \& Wilkins.

Kapri, U. C., \& Rani, N. (2014). Emotional maturity: Characteristics and levels. International Journal of Technological Exploration and Learning (Ijtel), 3(1), 359-361.

Karabanova, O. A., \& Poskrebysheva, N. N. (2013). Adolescent autonomy in parent-child relation. Procedia-Social 
and Behavioral Sciences, 86, 621-628. https://doi.org/10.1016/j.sbspro.2013.0 8.624

Liputo, S. (2014). Distress psikologik dan disfungsi sosial di kalangan masyarakat miskin kota Malang. Jurnal Sains dan Praktik Psikologi, 2(3), 286-295.

Marliani, R., Nasrudin, E., Rahmawati, R., \& Ramdani, Z. (2020). Regulasi emosi, stres, dan kesejahteraan psikologis: Studi pada ibu work from home dalam menghadapi pandemi COVID-19. Karya Tulis Ilmiah LP2M UIN SGD Bandung.

http://digilib.uinsgd.ac.id/30722/

Mondal, S., \& Sutradhar, A. (2015). Effect of home environment on different dimensions of emotional maturity of adolescent. The International Journal of Indian Psychology, 2(4).

Moeliono, M. F., Fitriana, E., Toharudin, T., Bektiningsih, D., Nelwan, P., Polhaupessy, L., \& Welzen. (2018). Panduan ringkas tes relasi keluargaBandung. PT. Mediabaca Mandiri.

Mulyadi, I. (2011). Melakukan segmentasi dengan demografi. https://marketing.co.id/demografisegmen-menengah-atas/

Murray, J. (2003). Are you growing up, or just getting older? http://www.sonic.net/ drmurray/maturi ty.htm.

Nashukah, F., \& Darmawanti, I. (2013). Perbedaan kematangan emosi remaja ditinjau dari struktur keluarga. Jurnal Psikologi: Teori \& Terapan, 3(2), 93102.

Oud, J. H., \& Welzen, K. (1989). De nijmeegse gezinsrelatie test: Kindeversie. Swets \& Zeitlinger.

Santiago, M. L., Benito, L. B., Maria, I. P. R., Rocio, Y. T., \& Victor, M. L. R. (2019). The role of parental acceptance-rejection in emotional instability during adolescence. International Journal of Enviromental Research and Public Health, 16, 1194. https://doi.org/10.3390/ijerph16071/11 94.

Santrock, J. W. (2014). Adolescence: $15^{\text {th }}$ edition. McGraw-Hill Education.

Singh, R., Pant, K., \& Dhyani, A. (2014). Role of economic classs in ascertaining and emotional maturity of adolescents. Anthropologist, $\quad 17(2), \quad 351-358$. https://doi.org/10.1080/09720073.2014 .11891444

Singh, Y., \& Bhargava, M. (1990). Manual for emotional maturity scale. Agra: National Psychological Corporation, 2(4), 16-18.

Skoczen, I., Cieciuch J., Oud, J. H. L., \& Welzen. (2015). Development and validation of the computerized family relations test for children. Front $\begin{array}{lll}\text { Psychol, } & 6, & \end{array}$ https://doi.org/10.3389/fpsyg.2015.016 87

Ucu, R. K. (2013). Anak yatim di Indonesia capai 3,2 juta. https://www.republika.co.id/berita/nasi onal/umum/13/04/01/mkk1kp-anakyatim-di-indonesia-capai-32-juta

Yuliawati, L., Setiawan, J. L., \& Mulya, T. W. (2007). Perubahan pada remaja tanpa ayah. Arkhe: Jurnal Ilmiah Psikologi, 12(1), 9-19.

Yuniana. (2012). Kesejahteraan subjektif pada yatim piatu (mustadh'afin) (Skripsi tidak diterbitkan). Fakultas Psikologi Universitas Ahmad Dahlan. 
Psympathic, Jurnal Ilmiah Psikologi Juni 2020, Vol. 7, No. 1, Hal. : 105-116 